\title{
PERDAMAIAN ACEH PASCA BENCANA TSUNAMI ACEH 2004 DAN MOU HELSINKI: TELAAH KRITIS DISASTER DIPLOMACY PEMERINTAH INDONESIA DALAM PENYELESAIAN KONFLIK ACEH
}

\author{
Mudjiharto \\ Universitas Muhammadiyah Yogyakarta \\ Email: mujibilang@gmail.com
}

\begin{abstract}
Abstrak
Tulisan ini membahas dan menganalisis tentang lima belas tahun perdamaian Aceh pasca bencana tsunami dan MoU Helsinki. Analisa tentang perdamaian Aceh lima belas tahun pasca bencana tsunami dan MoU Helsinki sangat penting, karena untuk mengetahui sejauhmana disaster diplomacy berkontribusi dalam proses peace building Aceh. Tulisan ini akan membahas dan menganalisis proses peace building Aceh, sejak dari upaya diplomasi sebelum bencana tsunami dan setelah bencana tsunami aceh, penandatangan MoU Helsinki sampai dengan proses peace building Aceh dewasa ini. Tulisan ini bertujuan untuk membuktikan tesis bahwa bencana bisa berfungsi sebagai sarana disaster diplomacy, dalam kasus ini adalah mengetahui sejauh mana bencana tsunami Aceh bisa berperan sebagai sarana disaster diplomacy dalam menciptakan perdamaian di bumi NAD, setelah lima belas tahun persitiwa bencana tsunami dan MoU Helsinki. Tulisan ini menggunakan pendekatan konsep Disaster diplomacy dan konsep Peace building. Tulisan ini didasarkan pada kajian dengan menggunakan metode kualitatif. Kesimpulan dari tulisan ini adalah Pemerintah Indonesia terbukti menggunakan disaster diplomacy dalam menyelesaikan konflik Aceh dengan GAM, yaitu dengan memanfaatkan momentum bencana tsunami Aceh untuk penyelesaian konflik Aceh. Disaster diplomacy Pemerintah Indonesia terbukti memiliki kontribusi dalam proses peace building Aceh, sehingga mampu mewujudkan perdamaian Aceh dalam jangka waktu yang lama, tidak sekedar pada saat perdamaian tersebut di tandatangani saja.
\end{abstract}

\section{Kata Kunci:}

Bencana Tsunami, Disaster Diplomacy, MoU Helsinki dan Peace Building

\begin{abstract}
This paper addresses and analyzes the fifteen years of peace in Aceh since the tsunami and MoU Helsinki. Analyzing Aceh peace after the disaster and MoU Helsinki was very important to understand how disaster diplomacy could make contribution to building pace in Aceh. This paper would discuss and analyze the Aceh peace building process, starting with the diplomacy process, before and after the tsunami hit Aceh. This paper aims to prove whether disaster could be used as diplomacy. In the case to know the process of disaster diplomacy to build peace in Aceh for 15 year, this paper used disaster diplomacy approach and the concept of peace building. This paper was based on a study using qualitative methods. The conclusion of this paper shows whether the
\end{abstract}


Government of Indonesia was using disaster diplomacy to settle the Aceh dispute with GAM (Gerakan Aceh Merdeka). Disaster diplomacy from Indonesian government was proven to have a major contribution to the process of peace building in Aceh over a long period of time, not just at the time when the peace treaty was signed.

Keywords:

Tsunami Disaster, Disaster Diplomacy, MoU Helsinki, Building Peace

\section{Pendahuluan}

Tanggal 26 Desember 2004, 15 tahun silam, menjadi momen duka bagi bangsa Indonesia, khususnya buat masyarakat Aceh. Hari itu, Aceh diguncang gempa bumi bermagnitudo 9,3 skala richter di dasar laut dengan kedalaman 10 kilometer yang lokasinya berjarak 149 kilometer dari Meulaboh. Setelah gempa, gelombang tsunami menyusul dengan kecepatan merambat 800 kilometer per jam, menerjang bumi Aceh. Sekitar 170 ribu orang meninggal, 114.897 korban hilang dan 412.438 korban terlantar akibat gempa dan tsunami tersebut. ${ }^{1}$ Namun bencana tersebut justru dianggap sebagai pintu masuk dan katalisator untuk mengakhiri konflik Aceh yang sudah berlangsung lama. Bahkan kemudian setelah 15 tahun berlalu, MoU Helsinki, perdamaian Aceh pasca tsunami dianggap bisa menjadi model buat resolusi konflik di tempat lain.

Sejarah konflik Aceh sendiri sangat panjang dan memprihatinkan. Konflik Aceh dimulai sejak tahun 1953, yaitu saat gerakan Darul Islam/Tentara Islam Indonesia (DI/TII) diproklamirkan oleh Teungku Daud Beureuh. Gerakan ini muncul dipicu dengan adanya kebijakan Pemerintah Pusat Jakarta menggabungkan Provinsi Aceh ke dalam Provinsi Sumatera Utara. Penggabungan dua provinsi ini berakibat masyarakat Aceh kehilangan hak istimewa untuk menjalankan syari'at Islam dalam kehidupan bermasyarakat dan bernegara. Bagi masyarakat Aceh yang religius, kebijakan Pemerintah Pusat tersebut direspon dengan pemberontakan bersenjata, karena dianggap merugikan masyarakat Aceh. Pemberontakan Darul Islam berakhir pada tahun 1959, dengan diberikannya status istimewa bagi Aceh berupa otonomi luas dalam bidang agama, adat, dan pendidikan. Dengan otonomi luas dalam bidang, agama, adat dan

\footnotetext{
${ }^{1}$ Arifin Sudirman \& Naura Nabila Haryanto, "Upaya Disaster Diplomacy Pemerintah Indonesia di Konflik Aceh 2005” dalam Sosiohumaniora - Jurnal Ilmu-ilmu Sosial dan Humaniora, Vol. 20, No. 3 (2018), h. 269.
} 
pendidikan, Aceh kembali berdiri sebagai provinsi sendiri dan memiliki kebebasan dalam menjalankan ketiga bidang tersebut. ${ }^{2}$

Kemudian konflik Aceh muncul kembali pada tahun 1976, yaitu saat Hasan Tiro memproklamirkan kemerdekaan Aceh, tepatnya pada tanggal 4 Desember 1976. Alasan utama Aceh ingin memisahkan diri dari Indonesia adalah karena GAM menganggap Pemerintah Indonesia telah melakukan ketidakadilan terhadap rakyat Aceh. Saat Pemerintah Indonesia melakukan eksploitasi pada sumber daya alam Aceh, rakyat Aceh tidak ikut menikmatinya dan hanya mendapat bagian penderitaannya saja. Padahal saat itu, Pemerintah Orde Baru melakukan eksploitasi besar-besaran untuk mengejar pertumbuhan ekonomi. Akibatnya rakyat Aceh menganggap Pemerintah Indonesia berbahagia di atas penderitaan rakyat Aceh.

Konflik Aceh menjadi berlarut-larut, karena ada perbedaan pandangan secara fundamental tentang pemilik kedaulatan atas Aceh yang sah, antara GAM dan Pemerintah Indonesia, sesuai dengan laporan International Crisis Group (ICG) tahun 2003. Dalam laporann ICG tersebut dijelaskan konflik Aceh terjadi dalam beberapa level. Pertama, konflik tersebut berangkat dari dua visi politik yang saling bertentangan. Pemerintah Indonesia beranggapan bahwa Aceh merupakan bagian tak terpisahkan dari Negara Kesatuan Republik Indonesia (NKRI) sejak proklamasi kemerdekaan Republik Indonesia. Di sisi lain, GAM berpandangan bahwa klaim Indonesia atas Aceh tidak berdasar, karena menurut GAM, Aceh tidak pernah ditaklukkan oleh Belanda sebelum proklamasi kemerdekaan. Maka dalam perspektif GAM, Aceh sudah merupakan entintas otonom sebelum Indonesia merdeka. Kedua, persoalan terjadi dalam perebutan kontrol terhadap sumber daya alam, di mana Pemerintah Indoensia dianggap mengeksploitasi Aceh tanpa memperhatikan kesejahteraan Aceh, yang merasa lebih berhak atas sumber daya alam Aceh. Ketiga, konflik juga terjadi berkaitan dengan penderitaan rakyat Aceh, ketidakadilan dan pelanggaran HAM oleh TNI dan Pemerintah Indonesia. Ketidakadilan dan pelanggaran HAM terbukti dengan diberlakukannya Aceh sebagai Daerah Operasi Militer (DOM). ${ }^{3}$

\footnotetext{
${ }^{2}$ M.Hamdan Basyar, "Peran Elit Lokal dalam Reintegrasi Gerakan Aceh Merdeka (GAM) Pasca MoU Helsinki" dalam Jurnal Penelitian Politik, Vol. 5, No. 1 (2008), h. 95.

3 Aleksius Jemadu, "Proses Peacebuilding di Aceh: Dari MoU Helsinki Menuju Implementasi Undang-undang tentang Pemerintah Aceh" dalam Jurnal Hukum Internasional, Vol. 3, No. 4 (2006), h. 533 .
} 
Di tengah konflik Aceh yang tak kunjung berakhir itu, bencana tsunami datang menghancurkan sebagian besar wilayah pantai Aceh. Bencana tsunami membuat momentum baru buat resolusi konflik Aceh. Karena kemudian pasca bencana, Pemerintah Indonesia dan GAM sepakat untuk tidak melanjutkan konflik di tengah penderitaan rakyat akibat bencana tsunami. Pemerintah Pusat dan GAM sama-sama menyadari, terus berkonfik dan melakukan kekerasaan dengan melakukan pendekatan militer, sama-sama merugikan kedua belah pihak. Meminjam istilah Zartman, kedua pihak yang berkonflik berada dalam situasi mutually hurting stalemate, yaitu dalam keadaan keadaan menderita karena kebuntuan konflik tersebut, menyadari tidak bisa mengabaikan konflik tersebut, dan tidak dapat meningkatkan sepihak untuk mendapatkan kemenangan. Dalam keadaan demikian, perdamaian adalah suatu keniscayaan dan pilihan terbaik.

Perundingan Helsinki yang sudah dipersiapkan sebelum peristiwa bencana, menjadi berlangsung dengan kesadaran baru, bahwa Aceh memang membutuhkan perdamaian untuk melanjutkan kehidupannya. Kedua belah pihak menyadari, Aceh tidak saja membutuhkan rekonstruksi yang cepat dan akurat, tetapi Aceh juga membutuhkan peace building karena tidak mungkin bantuan dunia interasional akan datang ke bumi Aceh, apabila Aceh dalam kondisi konflik. Masyarakat internasional jelas membutuhkan jaminan keamanan dan kerjasama pihak terkait dalam proses pengiriman bantuan buat rakyat Aceh. Sejarah kemudian mencatat bahwa perundingan Helsinki berhasil mengkahiri konflik dan menghadirkan perdamaian di Aceh. Pertanyaannya kemudian adalah sejauhmana kontribusi disaster diplomacy dalam proses perundingan Helsinki tersebut?.

Maka tulisan ini bertujuan untuk membuktikan tesis bahwa bencana bisa berfungsi sebagai sarana disaster diplomacy. Dalam kasus ini adalah mengetahui sejauh mana bencana tsunami Aceh, bisa berperan sebagai sarana disaster diplomacy dalam menciptakan perdamaian di bumi NAD, setelah 15 tahun persitiwa bencana tsunami terjadi dan MoU Helsinki ditandatangani. Untuk menjawab pertanyaan tersebut, tulisan ini menggunakan pendekatan konsep Disaster diplomacy dan konsep Peace building dalam melihat proses perdamaian Aceh sampai saat ini. 


\section{Konsep Disaster Diplomacy}

Konsep disaster diplomacy dikembangkan dan dipopulerkan oleh Ilan Kelman dan Theo Koukis pada Cambridge Review of Intaernational Affairs dengan tulisan “Disaster Diplomacy" yang diterbitkan pada tahun 2000. Tulisan tersebut merupakan tulisan Kelman dan Koukis yang bersandar pada analisa empat tulisan berbeda tentang bencana dalam empat studi kasus yang berbeda pula. Keempat tulisan itu dianalisa oleh Kelman dengan kacamata disaster diplomacy. Tulisan tersebut antara lain; tulisan James Ker-Lindsay tentang studi kasus hubungan Yunani dan Turki pasca bencana gempa, Ailsa Holloway membahas mengenai kekeringan di Afrika Selatan pada tahun 19911993, Michael H.Glantz membahas tentang badai yang menyelimuti Kuba-AS, dan Louise Comfort yang membandingkan ketiga tulisa tersebut melalui complex adaptive System framework. ${ }^{4}$

Globalisasi telah membuat bencana tidak lagi menjadi persoalan lokal semata, namun telah berubah menjadi persoalan global. Dewasa ini, isu bencana telah menjadi isu yang melintasi batas Negara. Misalnya adalah bencana asap di suatu negara, akan mempengaruhi kondisi sosial politik di negara lain, terutama di negara tetangga. ${ }^{5}$ Ratih dan Surwandono menyatakan bahwa disaster diplomacy dalam literatur dipahami sebagai studi tentang bagaimana dan mengapa bencana alam berkontribusi terhadap atau tidak terhadap perdamaian atau konflik, yang diteliti sebelum dan setelah bencana. Maksudnya adalah tidak setiap bencana berkontribusi terhadap keberhasilan disaster diplomacy, ada juga bencana yang tidak berkontribusi terhadap disaster diplomacy. Sehingga perlu penelitian yang bisa diketahui suatu bencana berkontibusi atau tidak pada disaster diplomacy. Dalam konteks sebelum bencana, diplomasi ini fokus meniliti tentang pencegahan, mitigasi dan upaya mengurangi jatuhnya korban bencana. Sedangkan dalam konteks setelah terjadi bencana, diplomasi ini meneliti tentang bagaimana konflik dan perdamaian dipengaruhi oleh bencana alam. ${ }^{6}$

Menurut Kelman konsep disaster diplomacy pada dasarnya varian dari kajian diplomasi yang menganalisis kemungkinan bencana alam dapat membuat peluang untuk

\footnotetext{
${ }^{4}$ Arifin Sudirman \& Naura Nabila Haryanto, Op. Cit., h. 270.

${ }^{5}$ Anita Afriani Sinulingga, "Isu Bencana dan Prinsip-Prinsip Humanitarian dalam Studi Hubungan International” dalam Andalas Journal of International Studies, Vol.5, No.1 (2016), h. 18.

${ }^{6}$ Ratih Herningtyas \& Surwandono, "Diplomasi Bencana Alam sebagai Saran Meningkatkan Kerjasama Internasional” dalam Jurnal Hubungan Internasional, Vol. 3, No. 2 (2014), h.183.
} 
memfasilitasi kerja sama yang secara alaminya "musuh" atau tidak. Lebih lanjut Kelman mengatakan bahwa disaster diplomacy mengarahkan kepada penelitian tentang bagaiman dan mengapa aktivitas yang berkaitan dengan bencana dapat dan/atau tidak dapat menginduksi kerjasama antara aktor-aktor internasional yang sebenarnya secara alami bermusuhan. ${ }^{7}$

Sementara Nathan berpendapat bahwa bencana merupakan suatu isu sosial yang berkaitan dengan resiko yang dihadapi suatu masyarakat. Di mana resiko (risk) masyarakat terhadap bencana merupakan perpaduan antara bahaya (hazard) dan kerentanan (vulnerability) terhadap kemampuan (capacities) masyarakat yang terkena dampak bencana. Dalam paper tersebut, Anita menyatakan bahwa isu bencana dapat berkaitan dengan kebijakan luar negeri dan diplomasi. Dalam kebijakan luar negeri, suatu bencana dapat dikapitalisasi sebagai keuntungan komparatif bagi suatu negara. Bahkan dalam perspektif yang lebih luas, suatu bencana bisa dijadikan nation branding atau image building, yang dapat digunakan dalam upaya mencapai tujuan luar negerinya. Sedangkan berkaitan dengan diplomasi, Anita menulis bahwa suatu bencana dapat dijadikan sarana diplomasi, karena diplomasi sekarang ini berkembang sedemikian luasnya, dalam hal ini muncul dalam bentuk diplomasi kemanusiaan. Hal ini terlihat dari munculnya aktor nom Negara dalam bidang kebencanaan. ${ }^{8}$

Setelah melakukan serangkaian penelitian tentang studi kasus, Kelman dan Koukis menyimpulkan bahwa aktivitas terkait kebencanaan dapat mempengaruhi, mendukung, mendorong, atau bahkan bisa jadi malah menghalangi proses diplomasi. Temuan lainya adalah tidak seluruh bencana dapat memiliki pengaruh yang kuat terhadap suatu konflik. Menurut Kelman, aktivitas terkait bencana baru bisa mendukung suatu proses diplomasi, apabila proses diplomasi tersebut sudah berlangsung sebelum adanya aktivitas terkait kebencanaan. Dalam jangka panjang faktor-faktor non-bencana lebih mempengaruhi secara siginifikan pada proses diplomasi dan perdamaian. Misalnya adalah ketidakpercayaan dan perubahan kepemimpinan dalam suatu pemerintahan yang sedang melakukan diplomasi. Hal inilah yang oleh Kelman disebut dengan disaster diplomacy.

\footnotetext{
${ }_{8}^{7}$ Arifin Sudirman \& Naura Nabila Haryanto, Loc.Cit.

${ }^{8}$ Anita Afriani Sinulingga, Op.Cit., h.21.
} 
Untuk melengkapi kesimpulan dari Kelman, pandangan Ratih dan Surwandono menarik dan dapat dijadikan rujukan dalam penelitian kebencanaan. Kedua penulis ini mangatakan konsep disaster diplomacy ini dapat diaplikasikan dalam hubungan antarnegara maupun intra-negara, sebagai bagian dari soft diplomacy. Namun keduanya juga memberikan catatan, bahwa bencana alam sendiri hanya akan berdampak dalam kerjasama dalam waktu yang terbatas, sehingga disaster diplomacy memerlukan diplomasi lain, sebagai dukungan dalam proses diplomasi, agar mewujudkan kapitalisasi yang subsisten. ${ }^{9}$

Penulis melihat Ian Kelman menawarkan sebuah konsep yang diharapkan mampu menjelaskan kaitan antara peristiwa bencana dengan proses diplomasi yang sedang berjalan bagi para aktor yang terlibat dan terdampak. Konsep ini, dalam hemat penulis, cukup mampu menjelaskan pola relasi terkait bagaimana peristiwa bencana mampu berpengaruh terhadap suatu aktivitas diplomasi. Walaupun dalam sisi lain, diplomasi bencana tidak selalu memberikan hasil yang positif. Namun dalam konteks teoritis penulis berpendapat bahwa konsep disaster diplomacy ini mampu digunakan sebagai alat analisis dalam memahami diplomasi pemerintah Indonesia dalam kaitannya dengan konflik di Aceh.

\section{Konsep Peace Building}

Johan Galtung memaparkan bahwa konsep peace buiding adalah proses pembentukan perdamaian yang tertuju pada implementasi praktis perubahan sosial secara damai melalui rekonstruksi dan pembangunan politik, sosial, dan ekonomi. Galtung menegaskan bahwa peace building lebih menekankan kepada proses jangka panjang, penelusuran, dan penyelesaian akar konflik, mengubah asumsi-asumsi yang kontradiktif, serta memperkuat elemen yang dapat menghubungkan pihak-pihak yang bertikai dalam suatu formasi baru demi mencapai perdamaian positif. ${ }^{10}$

Galtung dalam artikel berjudul "Three Approaches to Peace: Peacekeeping, Peacemaking and Peacebuilding" menyatakan bahwa perdamaian harus mempunyai sebuah struktur yang berbeda dengan saat konflik berlangsung, di mana dalam struktur

\footnotetext{
${ }^{9}$ Ratih Herningtyas \& Surwandono, Op.Cit., h.184.

${ }^{10}$ Subur Wahono, 'Implementasi Nota Kesepakatan (MoU) Helsinki di Provinsi Nangroe Aceh Darussalam Tahun 2005 sampai 2008". Tesis. (Jakarta: Program Pasca Sarjana Pengkajian Ketahanan Nasional, Universitas Indonesia, 2008), h.14.
} 
tersebut harus menghilangkan setiap benih konflik baru, baik yang berada dalam struktur pemerintahan, maupun konflik dalam suatu relasi sosial masyarakat. ${ }^{11}$ Dalam pengertian struktur baru hasil dari peace building, merupakan perdamaian tanpa menyimpan potensi terjadinya konflik lagi, baik di struktur pemerintahan maupun dalam masyarakat. Sehingga Galtung menegaskan bahwa peace building harus menghilangkan penyebab dasar dari konflik, maka perlu dukungan kapasitas lokal dalam mengelola perdamaian dan mengakhiri konflik. Dalam pandangan Galtung, fokus dari proses peace building adalah "the practical implementation of peaceful social change through social-economic recrontuction and development."

Hal ini menjadi catatan penting penting mengingat tujuan akhir dari peace building adalah menciptakan perubahan sosial yang dapat memberikan jalan keluar atau solusi bagi persoalan-persoalan yang selama ini menjadi sumber konflik. ${ }^{12}$ Artinya proses peace building mesti mengubah nilai-nilai negatif menjadi nilai-nilai positif. Pendekatan ini harus dilakukan dengan membangun relasi atas semua pihak-pihak yang berkonflik, dengan pendekatan yang komprehensif dan holistik. Baik hubungan dalam konteks spiritual, psikologi, maupun sosial, ekonomi dan budaya. Inilah suatu kondisi yang oleh Galtung disebut dengan perdamaian positif (positive peace), yaitu suatu kondisi damai secara struktural, baik dalam struktur relasi pengasa dengan rakyat, ataupun relasi rakyat dengan rakyat. Relasi secara struktural ini dibangun agar mampu menghilangkan ketidakpuasan yang bisa menimbulkan benih konflik baru pada masa berikutnya. Perdamaian positif ini merupakan perdamaian yang berbasis dasar pada nilai-nilai keadilan, persamaan, dan kesetaraan.

Perdamaian positif ini menurut Galtung memiliki tiga tipologi, yakni; Pertama, perdamaian positif langsung, yaitu berupa kebaikan yang ditunjukan untuk memenuhi kebutuhan dasar, kesejahteraan, kelangsungan hidup identitas, dan kebebasan. Kedua, perdamaian positif strukutural, yaitu mengganti penindasan dengan kebebasan dan eksploitasi dengan persamaan. Serta memperkuatnya dengan dialog, integrasi, soladaritas, dan partisipasi, bukan dengan melakukan penetrasi, segmentasi, fragmentasi, dan marginalisasi. Ketiga, perdamaian positif kultural, yaitu menggantikan

\footnotetext{
${ }^{11}$ Johan Galtung, "Three Approaches to Peace: Peacekeeping, Peacemaking and Peacebuilding" dalam Johan Galtung (ed.), Peace, War and Defense -Essays in Peace Research, Vol.2 (Copenhagen: Ejlers, 1976), h.282-304.

${ }^{12}$ Aleksius Jemadu, Op.Cit., h.529.
} 
legitimasi kekerasan dengan legitimasi perdamaian, baik dalam agama, ideology, hukum, bahasa, seni dan budaya.

Selain perdamaian positif, Galtung juga mengemukakan suatu kondisi perdamaian lain, yaitu suatu perdamaian yang masih mengandung adanya ketidakadilan didalamnya, hanya berupa suatu keadaan tanpa konflik kekerasan. Galtung menyebutnya dengan istilah perdamaian negatif (negative peace). Hal ini suatu perdamaian, seperti yang dikatakan Juha Christensen, fasilitator perdamaian Aceh, perdamaian bukan hanya soal tidak adanya konflik bersenjata, tetapi perdamaian adalah adanya keikhlasan sosial, kesehatan yang baik dan kemudian ekonomi yang tumbuh.

Merujuk kepada pendapat Galtung tersebut, tahapan berikutnya perlu dimanifestasikan dalam bentuk upaya peace building. Peace building di sini merujuk kepada upaya yang diusahakan secara signifikan dalam rangka mencipatakan perkembangan positif dan berkelanjutan yang mampu menjembatani pihak-pihak yang berkonflik. Tujuan dari hal tersebut pada dasarnya ialah untuk menciptakan fondasi komunikasi dan pemahaman bersama antara pihak yang berkonflik sehingga memungkinkan untuk kemudian tercipta dialog yang konstruktif dalam rangka menciptakan perdamaian positif. $^{13}$

Agar tujuan peace building dapat terwujud, Galtung juga membuat strategi pelaksanaan berupa tahapan waktu pelaksanaan perdamaian, dengan dua tahap agenda, yakni tahap transisi dan konsolidasi. Tahapan waktu tersebut meliputi; short-term (2 bulan-2 tahun), mid-term (2 - 5 tahun), dan long-term ( 5 - 10 tahun). Penelitian paper ini jika berdasarkan pada kategori tahapan waktu menurut Galtung, maka masuk dalam pelaksanaan perdamaian jangka panjang (long-term), karena penelitian ini dilakukan setelah 15 tahun peristiwa bencana tsunami dan MoU Helsinki.

\section{Disaster Diplomacy: Bencana Tsunami Aceh dan MoU Helsinki}

Disaster diplomacy dalam pelaksanaannya dibedakan menjadi dua konsep, sebagaimana dinyatakan oleh pendekar disaster diplomacy, Ilan Kelman, yaitu natural hazard dan natural disaster. Fenomena bencana alam dalam bentuk hazard tidak akan berubah menjadi disaster, dalam arti tidak akan berdampak destruktif, dengan catatan

${ }^{13}$ A. B. Fetherston, Towards a Theory of United Nations Peacekeeping (New York: St. Martin's, 1994), h.132. 
pencegahan dan persiapan termasuk secara teknis dan politis dilakukan dengan sebaik mungkin. Kalaupun disaster tidak dapat dihindari lagi, maka fenomena bencana tersebut jika dikelola sebaik mungkin, justru akan berubah jadi satu kekuatan bagi daerah atau Negara terdampak bencana alam. ${ }^{14}$

Bencana tsunami pada tahun Aceh 2004 oleh banyak pihak dianggap sebagai salah satu bencana yang dapat berkontribusi pada proses disaster diplomacy bagi daerah terdampak yang kebetulan sedang dilanda konflik. Seperti sudah ditulis sebelumnya, Aceh merupakan wilayah Indonesia yang sudah sejak lama tidak bisa merasakan perdamaian, di mana sejarahnya selalu diisi dengan konflik dan kekerasan militer. Pergolakan DI/TII Teungku Daud Beureuh berhenti, selang beralama perdamaian, Aceh berada dalam konflik dengan munculnya GAM Hasan Tiro. Perdamaian Aceh baru muncul setelah bencana tsunami 2004, diiringi dengan segala prosesnya.

Fenomena itu membuat banyak pihak menyimpulkan perdamaian Aceh merupakan berkah dan akibat dari adanya bencana tsunami. Dalam proses penulisan paper ini, penulis menemukan, bahwa fenomena hazard dalam bencana tsunami Aceh dapat berkontribusi menjadi disaster diplomacy, di mana disaster tersebut dapat mengubah konflik Aceh yang sudah berlarut-larut menjadi perdamaian di Aceh. Namun tidak semua pihak mengetahui, bahwa peace building Aceh tersebut sesungguhnya sudah berproses jauh sebelum bencana tsunami terjadi.

Namun untuk mengetahui apakah dalam bencana tsunami Aceh ada aktivitas kebencanaan atau disaster related activities sebagai bagian dari implementasi disaster diplomacy dibutuhkan beberapa penjelasan. Penjelasan tersebut berupa respon Pemerintah Indonesia, GAM dan aktor internasional, yang menjelaskan bahwa peristiwa bencana tsunami menuntun aktivitas yang mengarah kepada aktivitas kebencanaan, dan pada gilirannya aktivitas kebencanaan itu bermuara pada interaksi diplomasi.

Respon Pemerintah Indonesia tentang bencana tsunami, dalam tulisan ini diwakili oleh pernyataan Presiden Susilo Bambang Yudoyono (SBY) dan Wapres Jusuf Kalla. Pada hari kejadian bencana, SBY langsung mendeklarasikan bencana alam dan memerintahka berbagai departemen dan kementerian untuk melakukan mobilisasi sumber daya yang ada, proses rehabilitasi dan rekonstruksi serta memberi tugas Badan

\footnotetext{
${ }^{14}$ Ratih Herningtyas \& Surwandono, Loc.Cit., h. 183.
} 
Nasional Penaggulangan Bencana (BNPB) untuk menerjunkan personelnya ke tempat terjadinya bencana. ${ }^{15}$ SBY juga menyerukan kembali pentingnya perundingan damai, dan meminta kesedian mantan Presiden Finlandia Martti Ahtisaari dan lembaganya Crisis Management International (CMI) untuk menjadi mediator perundingan.

Untuk menunjukan komitmen kedua belah pihak dalam mewujudkan perdamaian, SBY memerintahkan Badan Perencanaan Pembangunan Nasional (BAPPENAS) untuk membuat Master Plan, dan SBY membuat Badan Pelaksana Rehabilitasi dan Rekonstruksi Aceh Nias (BAPEL) untuk mengimplementasikan Master Plan tersebut. Adapun Master Plan tersebut, yaitu; Pertama, mengembalikan infrastruktur publik semisal jalan dan sekolah. Kedua, melakukan stimulasi terhadap ekonomi lokal. Ketiga, mengembalikan fasilitas publik untuk mendukung aktivitas ekonomi seperti pasar. Keempat, memberikan keamanan lanjutan bagi komunitas Aceh untuk mengantisipasi bencana alam selanjutnya apabila akan datang. ${ }^{16}$

Sementara Jusuf Kalla memberikan respon terkait kejadian bencana dan merespon konflik Aceh dengan menugaskan Hamid Awaludin sebagai Mentri Hukum dan HAM untuk melakukaan perdamaian. Dengan lugas Jusuf Kalla mengatakan, “Aceh harus segera damai. Tidak mungkin suplai makanan bisa berjalan lancar, kalau masih ada letusan senjata. Apa yang terjadi jika ada orang internasional yang tengah membantu Aceh tetiba dibunuh atau diculik? Mereka berlarian pergi, membuat rakyat Aceh dan Nias kian menderita."17

Di lain pihak, Gerakan Aceh Merdeka (GAM) langsung mengumumkan genjatan senjata secara sepihak dan menyatakan bersedia ikut serta dalam proses pemberian bantuan kemanusian dari masyarakat internasional. ${ }^{18}$ Sementara respon internasional dalam bencana Aceh ditunjukan dengan tidak main-main, hal ini dapat dilihat dari besarnya bantuan kemanusian yang diberikan kepada bencana tsunami Aceh. Masyarakat internasional mengakui bahwa bantuan kemanusiaan yang diberikan kepada Aceh merupakan respon internasional terbesar dalam merespon bencana alam dan juga respon finansial tercepat terhadap bencana. UN's Financial Tracking System dalam laporannya menginformasikan bahwa 1 milyar dolar AS diterima pemerintah

\footnotetext{
${ }^{15}$ Arifin Sudirman \& Naura Nabila Haryanto, Op.Cit., h. 271.

${ }^{16}$ Ibid., h. 272.

${ }^{17}$ Ibid., h. 271.

${ }^{18}$ Aleksius Jemadu, Op.Cit., h. 532.
} 
untuk Aceh dari pendonor, dengan Amerika, Australia, dan Jepang sebagai pendonor terbesar. Belum lagi bantuan melalui PBB sebesar 1,1 milyar dolar AS untuk menyediakan makanan, obat-obatan, air bersih, dan penampungan sementara untuk korban bencana. ${ }^{19}$

Dari deskripsi di atas, terlihat bahwa bencana tsunami Aceh bisa berkontribusi pada aktivitas diplomasi dan berhasil dikelola secara baik oleh Pemerintah Indonesia dan didukung oleh kemauan yang sama dari pihak GAM. Bencana tsunami mengubah ideologi Pemerintah Indonesia dan GAM untuk damai. Sebelum terjadinya bencana, kedua belah pihak bersikeras untuk mempertahankan kepentingan masing-masing tanpa kompromi. Namun bencana tsunami membuat kedua belah pihak bersedia mengesampingkan kepentingannya tersebut. Kedua belah pihak menyadari rekonstruksi Aceh merupakan kebutuhan Aceh yang mendesak dan sebenarnya.

Pemerintah Indonesia menyadari untuk dapat melaksanakan rekonstruksi maka perdamaian adalah pilihan yang paling rasional. Karena dalam keadaan konflik tidak mungkin dapat melaksanakan rekonstruksi pasca tsunami. Sementara GAM sendiri menyadari apabila tetap dengan tuntutan merdeka, maka Aceh belum tentu mampu membangun negara sendiri, apalagi dalam keadaan GAM tidak memiliki dukungan internasional untuk merdeka.

Namun hal tersebut tidak terjadi secara tetiba, sesugguhnya semua proses sudah berlangusng lama, melewati beberapa kegagalan, dan melalahkan secara mental, serta menghabiskan biaya yang tidak sedikit jumlahnya. Sebelum MoU Helsinki, pada masa pemerintahan Presiden Abdurahman Wahid dan Presiden Megawati Soekaro Putri, sebenarnya sudah berlangsung proses peace building, namun momentum tersebut belum berhasil dimanfaatkan secara maksimal. Tanpa proses perdamaian sebelumnya, bisa jadi aktivitas disaster diplomacy berkaitan dengan bencana tsunami Aceh belum tentu menghasilkan perdamaian.

Momentum perdamaian saat itu adalah; Pertama, pada Mei 2000 Pemerintah Indonesia dan GAM menandatangani Kesepahaman Bersama Jeda Kemanusiaan. Jeda Kemanusiaan digagas dengan tujuan untuk mengurangi kekerasan di Aceh, menyalurkan bantuan kemanusiaan, dan sekaligus untuk meningkatkan kepercayaan

\footnotetext{
${ }^{19}$ Arifin Sudirman \& Naura Nabila Haryanto, Op.Cit., h. 273.
} 
masyarakat dan dunia internasional kepada pemerintah dan GAM. Jeda Kemanusiaan yang difasilitasi oleh HDC tidak bisa berlangsung lama. Kedua, pada tahun 2002 Pemerintah Indonesia dan GAM kembali menandatangani lagi kesepakatan baru, yang dikenal sebagai Cessation of Hostility Agreement (CoHA). Sebagai hasil kesepakatan, juga berhasil dibentuk zona damai, tetapi kesepakatan perdamain itu tetap tidak berlangsung lama, padahal dalam perjanjian tersebut sudah melibatkan tim pemantau dari Negara-negara ASEAN, yang tergabung dalam Joint Securty Committee (JSC).

Baru setalah MoU Helsinki, konflik Aceh yang sudah berlangsung lama dapat diakhiri, dan perdamaian baru bisa mulai bersemi di bumi Aceh. MoU Helsinki sendiri berhasil disepakati Pemerintah Indonesia dan GAM pada tanggal 15 Agustus 2005. MoU ini berisi tentang beberapa kesepakatan, yaitu; Pertama, mengatur penyelenggaraan pemerintahan Aceh. Termasuk kedalam point ini adalah pembuatan Undang-undang Pemerintah Aceh, partisipasi partai politik dan masalah ekonomi. Dalam masalah politik memuat aturan tentang pendirian partai lokal, pengaturan perundang-undangan, sedangkan dalam masalah ekonomi termasuk mengatur pembagian hasil sumber daya alam di mana disebutkan Aceh berhak mendapat $70 \%$ dari kekayaan alam tersebut.

Dalam point kedua, disebutkan masalah Hak Asasi Manusia, di mana di dalamnya menerangkan mengenai pembentukan pengadilan HAM dan Komisi Kebenaran dan Rekonsliasi (KKR). Point ketiga, MoU tersebut mengatur pemberian amnesti dan upaya reintegrasi mantan kombatan GAM dan tahanan politik ke dalam masyarakat. Termasuk ke dalam agenda ini adalah disarmament (pelucutan senjata) dan demobilization (penarikan pasukan). Pelucutan senjata yang dimaksud berupa pelucutan senjata yang digunakan oleh kombatan GAM, sedangkan penarikan pasukan merupakan upaya pemulangan TNI dari Aceh.

Proses perundingan Helsinki sendiri, sebenarnya prosesnya sudah berlangsung sebelum bencana tsunami terjadi. Terpilihnya SBY dan Jusuf Kalla secara langsung memberi legitimasi yang kuat bagi keduanya dalam mengambil langkah terobosan perdamaian Aceh. Jusuf Kalla mulai melakukan pendekatan ke GAM melalui salah satu pengusaha asal Aceh, Rusli Bintang. Langkah Jusuf Kalla lebih mantap karena semenjak masih menjabat menteri di era Presiden Megawati sudah mencoba membangun komunikasi dengan pihak GAM. Jusuf Kalla langsung membentuk Tim 
yang melibakan Hamid Awaludin, Sofyan Abdul Djalil dan Mayjen Syarifudin. Tim ini berkomunikasi secara informal dengan petinggi GAM, yaitu Muzakir Manaf, Sofyan Ibrahim Tiba dan beberapa tokoh GAM di level kabupaten. ${ }^{20}$

\section{Peace Building Aceh: MoU Helsinki dalam Ujian Sejarah}

Sejak Negara Kesatuan Republik Indonesia berdiri, konflik antara Aceh dengan Pemerintah Indonesia sudah terjadi dua kali, sebagaimana sudah pernah disebutkan di atas. Pertama, konflik Darul Islam/Tentara Islam Indonesia (DI/TII) pada tahun 19531962 dan kedua, konflik GAM dari tahun 1976-2005. Namun kedua konflik tersebut berbeda secara karakteristik dan berbeda tujuannya. Konflik DI/TII bertujuan memperoleh otonomi, sementara konflik GAM bertujuan memperoleh kemerdekaan bagi Aceh.

Kedua konflik memang pada akhirnya dapat diselesaikan melalu kesepakatan damai, namun proses perdamaian kedua konflik sangat berbeda. Proses perdamaian pada konflik pertama bersifat hubungan asimetris, sementara dalam konflik kedua hubungan bersifat simetris. Konflik pertama dikatakan bersifat asimetris, karena Pemerintah Indonesia lebih mendominasi dalam perundingan. Dominasi Pemerintah Indonesia terlihat dari pendekatan militer yang dikombinasikan dengan pendekatan persuasif dialogis, bahkan dalam penyelesaiannya Indonesia diwakili oleh Pemerintah Daerah. Hasilnya pernyataan menyerah dari kelompok DI/TII Daud Beureuh. Sementara dalam konflik kedua, dikatakan bersifat simetris karena kesepakatan damai berupa Nota Kesepahaman (Memorandum of Uderstanding/MoU) Helsinki yang prosesnya seimbang (simetris) dan dimediasi oleh pihak ketiga, mantan Presiden Finlandia Martti Ahtisaari. $^{21}$

Dalam buku Rebellion Under The Banner of Islam (1981), Cornelis Van Dijk mengatakan bahwa konfik pertama disebabkan oleh kekecewaan ideologis, sosial, politik, ekonomi, dan budaya terhadap Pemerintah Indonesia. Islam merupakan identitas politik dan budaya masyarakat Aceh, sehingga terus menjadi diskursus antara Aceh dan Pemerintah Indonesia. Maka ketika disepakati perjanjian yang menjamin keistimewaan

${ }^{20}$ Tim Penulis Salemba Tengah, Mengawal Demokrasi: Pengalaman Jaringan Demokrasi Aceh dan RUUPA (Jakarta: YAPPIKA, 2007), h. 20.

${ }^{21}$ Suadi Zainal, "Transformasi Konflik Aceh dan Relasi Sosial Politik di Era Desentralisasi" dalam Masyarakat Jurnal Sosiologi, Vol. 21, No. 1 (2016), h. 87. 
pemberlakuan syariat Islam di Aceh dalam bidang agama, hukum, adat dan pendidikan, secara otomatis konflik DI/TII berakhir. ${ }^{22}$

Perdamaain hasil kesepakatan di atas mampu bertahan selama belasan tahun. Akan tetapi keistimewaan tersebut tidak dapat direalisasikan, terutama saat Presiden Soeharto dan Orde Baru berkuasa. Orde Baru mengeksploitasi kekayaan alam Aceh tanpa didistribusikan kembali secara adil. Otonomi pengelolaan daerah lebih bersifat simbolik daripada substantif. Persoalannya adalah ketika hal ini diingatkan oleh Aceh, pemerintah meresponnya dengan negatif atau berlebihan. Maka konfik pun tak bisa dihindarkan, kemudian munculah Gerakan Aceh Merdeka pada tahun 1976.

Penyelesaian konflik kedua sudah dijelaskan di atas, yang mana konflik kedua berakhir dengan disepakatinya perjanjian Helsinki. Menyinggung kembali dan sekaligus membadingkan kedua konflik tersebut, dengan tujuan untuk membantu menganalisis perdamaian Aceh secara mendasar. Karena peace building membutuhkan tidak sekedar perjanjiann secara formal yuridis, namun upaya implentasinya secara faktual dan permanen. Karena perdamaian tidak bisa dilihat hasilnya dalam jangka pendek saja, namun baru bisa dilihat dalam jangka panjang.

Sejarah kesepakatan perjanjian DI/TII bisa menjadi pelajaran berharga, di mana perdamaian sebagai implementasi kesepakatan perjanjian DI/TII hanya berlangsung belasan tahun. Hal itu terjadi karena kesepakatan perjanjian dalam prakteknya tidak dilaksanakan. Kesepakatan perjanjian dilaksanakan hanya dalam tataran simbolik semata, dan secara substansi kesepakatan tersebut diabaikan begitu saja. Belajar dari sejarah sebelumnya, maka biarpun implementasi MoU Helnsinki sudah berlangsung 15 tahun, tetap perlu untuk terus dikaji sejauhmana implentasinya, karena tidak ada jaminan perdamaian Aceh akan terus berlangsung.

\section{Telaah Kritis Lima Belas Tahun Perdamaian Aceh}

Perdamaian bukan sesuatu yang mudah didapatkan. Perdamaian membutuhkan kesungguhan, komitmen, pengorbanan, kerja sama dan tentu juga waktu dalam pelaksanaannya. Maka agar tujuan peace building dapat terwujud dan berhasil, untuk tujuan tersebut, Galtung membuat strategi pelaksanaan berupa tahapan waktu

\footnotetext{
${ }^{22}$ Ibid., h. 86.
} 
pelaksanaan perdamaian, dengan dua tahap agenda kerja, yakni tahap transisi dan konsolidasi. Tahapan waktu tersebut meliputi; short-term (2 bulan-2 tahun), mid-term (2-5 tahun) dan long-term (5-10 tahun). Penelitian paper ini juga menggunakan pembagian kategori waktu berdasarkan tahapan waktu Galtung tersebut untuk memudahkan dalam mengukur keberhasilan implementasi perdamaian di bumi Serambi Mekah.

Berarti jika berdasarkan pada kategori tahapan waktu menurut Galtung di atas, maka penelitian ini sudah lebih dari cukup untuk meneliti implementasi perdamaian Aceh dengan kategori jangka panjang. Karena penelitian ini dilakukan, setelah 15 tahun sejak peristiwa bencana tsunami dan MoU Helsinki. Dengan demikian hasil penilaian terhadap peace bulding Aceh sebagai disaster diplomacy sudah memenuhi standar keilmuan. Hal ini penting untuk memastikan bahwa aktivitas disaster diplomacy dalam bencana tsunami Aceh memang benar ada dan sekaligus juga bisa diketahui keberhasilannya dalam mewujudkan perdamaian di Aceh.

Pada bagian berikut akan ditelusuri proses peace building Aceh, sejak terjadinya bencana tsunami, terutama sejak MoU Helsinki, dengan menggunakan tiga tahapan kategori waktu Galtung. Pertama, kategori short-term (2 bulan-2 tahun). Pada waktu terjadi bencana tsunami, sebenarnya perundingan Helsinki dalam tahapan persiapan, dengan didahului berbagai pembicaraan informal tingkat tinggi. Pertemuan informal tingkat tinggi tersebut berupa pembicaraan Jusuf Kalla dengan pimpinan militer GAM Muzakir Manaf. Dalam Pembicaraan informal keduanya menyepakati beberapa isu penting seperti pelaksanaan otonomi khusus secara penuh, kompensasi ekonomi, pembangunan masjid dan amnesti, namun untuk keabsahannya perlu perundingan lebih lanjut dengan pimpinan GAM di Swedia. ${ }^{23}$

Begitu terjadi tsunami GAM menyatakan genjatan senjata sepihak dan bersedia meneruskan agenda perundingan dengan Pemerintah Indonesia serta bersedia kerjasama dalam rehabilitasi dan rekonstruksi Aceh pasca bencana tsunami. Begitu juga Pemerintah Indonesia menyadari sepenuhnya pentingnya suasana damai di Aceh untuk memudahkan pelaksanakan agenda disaster. Terutama pemerintah Indonesia

\footnotetext{
${ }^{23}$ Aleksius Jemadu, Op.Cit., h. 531-532.
} 
memperhitungkan national image di dunia internasional dan jelas Pemerintah Indonesia tidak mau mempertaruhkan national image tersebut.

Sikap GAM dan Pemerintah Indonesia di atas, yaitu sikap kedua belah pihak dalam menyikapi bencana tsunami Aceh merupakan respon terhadap situasi mutually hurting stalemate. Kedua belah pihak berada dalam keadaan menderita karena kebuntuan konflik dan tidak bisa melanjutkan konflik karena hanya akan membawa pada kerugian lebih besar dan tidak mungkin membuat salah satunya keluar sebagai pemenang. Dalam perspektif demikian, maka asumsi bahwa bencana tsunami merupakan penyebab adanya perdamaian Aceh dapat diterima.

Berangkat dengan kesadaran pentingnya perdamaian Aceh pasca bencana tsunami, Muhammad Nazar (Ketua SIRA) mengirim surat kepada Presiden Indonesia dan Perdana Menteri GAM. Dalam isi surat tersebut Nazar mendorong dan mendesak semua pihak terkait untuk segera memajukan proses perdamaian kembali dan menjadikan bencana tsunami sebagai titik tolak untuk menegakkan kebebasan, keadilan, HAM dan perdamaian di Aceh. ${ }^{24}$ Surat perdamaian dari Nazar menggambarkan suasana batin masyarakat Aceh yang sesungguhnya.

Akhirnya babak baru perdamaian Aceh terwujud dengan disepakatinya MoU Helsinki pada tanggal 15 Agustus 2005 antara GAM dengan Pemerintah Indonesia. Perdamaian Helsinki disambut dengan antusias oleh masyarakat Aceh. Masyarakat Aceh menganggap MoU Helsinki sebagai harapan baru bagi masa depan perdamaian Aceh, meskipun masih dibayangi kegagalan seperti perjanjian-perjanjian sebelumnya. Namun harapan itu tumbuh bersama dengan implementasi kesepakatan perdamaian Helsinki. Hal penting pertama yang dilaksanakan kedua belah pihak yang berkonflik adalah menangani sektor keamanan. Kedua belah pihak menyadari konflik kekerasan pasca kesepakatan damai akan berdampak buruk bagi proses peace building Aceh selanjutnya. Kesungguhan untuk mewujudkan perdamaian terlihat dalam pelaksanaan pelucutan senjata GAM maupun penarikan pasukan TNI yang berlangsung dengan baik tanpa hambatan yang berati. Fakta tersebut jelas berbeda dengan keadaan sebelum MoU Helsinki di mana GAM dan TNI sering terlibat dalam kekerasan bersenjata. ${ }^{25}$

\footnotetext{
${ }^{24}$ Arifin Sudirman \& Naura Nabila Haryanto, Loc.Cit.

${ }^{25}$ Aleksius Jemadu, Op.Cit., h. 535.
} 
Modal dasar bagi peace building Aceh yang paling berharga adalah dengan pengesahan Rancangan Undang-undang Pemerintah Aceh (UUPA) pada tanggal 1 Juli 2006. UUPA ini merupakan kristalisasi dan sekaligus penjabaran dari MoU Helsinki. Undang-undang ini merupakan legitimasi bagi pelaksanaan peace building Aceh. Penandatanganan UUPA ini jelas langkah maju bagi masa depan perdamaian Aceh. Undang-undang ini merupakan hasil dari proses bersama antara Aceh dan Pemerintah Indonesia, sehingga menampilkan warna spirit politik identitas Aceh dan mengakomodir keadilan ekonomi bagi masyarakat Aceh, dengan berbagai kelebihan dan kekurangannya.

Namun tantangan bagi perdamaian Aceh pada saat itu masih berat dan terjal. Karena sebagian anggota GAM masih menganggap MoU Helsinki hanya sebagai sarana untuk proses menuju persiapan kemerdekaan. Pandangan demikian terutama masih dipegang oleh GAM di kalangan akar rumput. Hasil Survei LSI memperkuat dugaan terhadap GAM itu, yaitu mengatakan bahwa enam dari sepuluh orang berpendapat kalau GAM masih menginginkan kemerdekaan. Tetapi kesungguhan pemerintah dalam menangani rahabilitasi dan rekonstruksi membuat perdamaian Aceh dirasakan sendiri oleh masyarakat Aceh. Hal ini terlihat dari hasil survei LSI di waktu berikutnya. Dalam hasil survey ditemukan bahwa 67\% masyarakat Aceh merasa puas dengan hasil perdamaian saat itu. Survei LSI saat itu, juga mengungkap salah satu kerikil tajam bagi perdamaian Aceh, berupa pandangan survei LSI di level nasional, di mana 81,2\% publik nasional menginginkan GAM berinisiatif membubarkan diri. ${ }^{26}$

Kedua, kategori mid-term (2 - 5 tahun). Perlu untuk menjadi catatan, penandatanganan MoU Helsinki tidak serta merta mengakhiri konflik Aceh. Kesepakatan damai tersebut baru bisa menghasilkan kesepakatan untuk menyelesaikan konflik tanpa kekerasan. Sedangkan konflik dalam perbedaan pandangan dan tujuan masih terus berlangsung, biarpun dalam ekskalasi yang terus menurun. Sampai dalam posisi ini, perdamaian Aceh oleh Galtung disebut dengan negative peace, tidak adanya kekerasan (the absence of violence) dalam mencapai tujuan masing-masing dari pihakpihak yang berkonflik.

${ }^{26}$ ANTARANEWS, "67 Persen Publik Aceh Puas Dengan Perdamaian Yang Tercipta" dalam https://www.antaranews.com/berita/39859/67-persen-publik-aceh-puas-dengan-perdamaian-yang-tercipta diakses 1 Januari 2020. 
Pandangan Galtung di atas, terlihat secara nyata dalam realitas proses peace building berupa keberadaan GAM itu sendiri. Sehingga 3 tahun MoU Helsinki, GAM masih tetap eksis dan tidak pernah dibubarkan. Pembubaran hanya dilakukan pada tataran Tentara Neugara Aceh (TNA) yang selama ini dikenal sebagai Angkatan Gerakan Aceh Merdeka (AGAM). Sementara GAM sendiri sebagai social-political movements masih tetap eksis dan berperan sebagai organisasi tertinggi dalam mengambil keputusan dalam kelompok ini. ${ }^{27}$ Padahal sebagaimana sudah disebutkan di atas pada tahun pertama perdamaian, publik nasional sudah menginginkan GAM berinisiatif untuk membubarka diri.

Konflik vertikal antara Pemerintah Indonesia dan Aceh bisa dikatakan turun ke level keadaan damai, tetapi konflik horizontal muncul. Konflik ini berupa ada keinginan sebagian anggota masyarakat untuk mendirikan provinsi baru dan juga berbentuk persaingan dalam perebutan episentrum politik, sebagai dampak diterapkannya pilihan langsung dan diperbolehkannya pendirian partai lokal. Potensi konflik lain diakibatkan oleh adanya dana rehabilitasi dan rekonstruksi serta dana kompensasi bagi mantan kombatan GAM.

Ketiga, kategori long-term. Setelah sepuluh tahun MoU Helsinki Aceh masih dalam keadaan damai tanpa kekerasan senjata. Juha Christensen, Aliansi Arssitek Perdamaian dan Tarnsformasi Konfik (PACTA), mengatakan memang MoU Helsinki belum semuanya terlaksana, namun perdamaian Aceh sudah bisa dijadikan model percontohan bagi konflik di wilayah lain. Juha memberi contoh, dalam kesepakatan disepakati untuk saling percaya satu sama lainnya, tetapi dalam kenyataannya hal itu belum terwujud. Justru masih ada keraguan dan sikap saling mencurigai. Juha memberi bukti berupa fakta lambatnya implementasi Peraturan Presiden tentang Kewenangan Pemerintah Aceh terhadap pertanahan, minyak dan gas serta lautan di Aceh. Sementara di sisi lain, pemerintah pusat masih mencurigai Pemerintah Aceh terkait dengan masih munculnya Qonun atau aturan tentang bendera Aceh, di mana bendera tersebut menggunakan bendera yang sama dengan bendera GAM. ${ }^{28}$

\footnotetext{
${ }^{27}$ Moch. Nurhasim, "Transformasi Gerakan Aceh Merdeka (GAM)" dalam Jurnal Penelitian Politik, Vol. 6, No. 1 (2009), h. 86.

28 Fathiyah Wardah, "Perjanjian Helsinki Bisa Jadi Model Penyelesaian Konflik" dalam https://www.voaindonesia.com/a/perjanjian-helsinki-bisa-jadi-model-penyelesaian-konflik/ 3058701.html diakses 1 Januari 2020.
} 
Salah satu isu sensitif terbaru adalah pernyataan tentang referendum yang dikeluarkan oleh Ketua Dewan Pimpinan Aceh (DPA) Partai Aceh, Muzakir Manaf, pada peringatan kesembilan tahun wafatnya Wali Neugara Aceh, Paduka yang Mulia Tgk. Muhamad Hasan Tiro. Biarpun wacana referendum Aceh ini dianggap sebagai potret buram terhadap hegemoni politik yang berlangsung di Aceh dan dianggap tidak mewakili suara mayoritas masyaraka Aceh, seperti dikatakan oleh Amir Faisal, pendiri The Atjeh Conection Foundation. ${ }^{29}$ Namun paling tidak ini tetap menjadi catatan tersendiri, bahwa perdamaian Aceh belum sepenuhnya aman dan bisa saja suatu saat muncul konflik lagi dan tantangan sejenis di tempat berbeda.

Rizal Sukma memberi empat argumen mengapa MoU Helsinki bisa mengawal peace building di Aceh, yaitu; Pertama, tidak seperti dua kesepakatan sebelumnya, Jeda Kemanusian dan CoHA yang berfokus pada penghentian konflik senjata di lapangan, MoU Helsinki merupakan kesepakatan komprehensif dalam penyelesaian konflik Aceh. Kedua, pertama kalinya pihak-pihak yang menandatangani MoU memanfaatkannya untuk pelucutan senjata, demobilisasi dan integrasi. Ketiga, MoU mengatur serangkaian isu luas, mulai dari isu hukum, pemerintahan, status Aceh, partisipasi politik, insentif ekonomi, hak asasi dan rekonsliasi. Keempat, MoU juga menyediakan mekanisme implementasi, termasuk tata kelembagaan dan mekanisme penyelesaian sengketa. ${ }^{30}$

Ada satu hal lagi yang penting untuk menjadi catatan, yakni kesenjangan ekonomi dan kesejahteraan Aceh, setelah 15 tahun kesepakatan perdamaian belum bisa terwujud. Sampai detik ini, Aceh masih berpredikat sebagai provinsi termiskin di Sumatera. Dari data Badan Statistik Nasional (BPS) per Sepetemer 2019, diketahui data jumlah pendidik miskin di Aceh berjumlah 810.000 orang atau 15,01\%. Selain itu ditemukan fakta, dari sisi pendidikan tercatat penduduk miskin yang bekerja sebagian besar berpendidikan SD/sederajat, yaitu 46,29\%. ${ }^{31}$ Data tersebut menunjukan dari segi

\footnotetext{
${ }^{29}$ Muhammad Agil Aliansyah, "Wacana Referendum Dinilai Tak Mewakili Aspirasi Msyarakat Aceh” dalam https://www.merdeka.com/peristiwa/wacana-referendum-dinilai-tak-mewakili-aspirasimasyarakat-aceh.html diakses 1 Januari 2020.

30 Rizal Sukma, "Mengelola Perdamaian di Aceh: Tantangan Pemeliharaan Pasca Konflik" dalam Patrick Daly (eds.), Aceh Pascatsunami dan Pascakonflik (Jakarta: Pustaka Larasan, ICAIOS, dan KITLV-Jakarta, 2012), h. 269.

${ }^{31}$ Nuri Taufiq, "Fakta-fakta Seputar Aceh sebagai Provinsi Termiskin di Sumatera" dalam https://news.detik.com/kolom/d-4877496/fakta-fakta-seputar-aceh-sebagai-provinsi-termiskin-di-suma tera diakses 1 Februari 2020.
} 
substantif, perdamaian Aceh belum bisa dikatakan sebagai perdamaian positif (positive peace). Dengan kata lain, perdamaian Aceh masih bersifat perdamaian negatif (negative peace).

\section{Kesimpulan}

Kesimpulan dari tulisan ini adalah Pemerintah Indonesia terbukti menggunakan disaster diplomacy dalam menyelesaikan konflik Aceh dengan GAM, yaitu dengan memanfaatkan momentum bencana tsunami Aceh untuk penyelesaian konflik Aceh. Disaster diplomacy Pemerintah Indonesia terbukti memiliki kontribusi dalam proses peace building Aceh, sehingga mampu mewujudkan perdamaian Aceh dalam jangka waktu yang lama, tidak sekedar pada saat perdamaian tersebut ditandatangani saja.

Namun keberhasilan Pemerintah Indonesia baru dapat mewujudkan perdamaian negatif (negative peace), belum bisa mewujudkan perdamaian positif (positive peace). Biarpun sudah 15 tahun perjanjian Helsinki disepakati. Dalam artian, perdamaian Aceh baru dalam tahap tidak adanya konfik dengan menggunakan kekerasan atau menggunakan senjata atau tidak ada perang. Sementara perdamaian dalam makna persamaan, keadilan dan kesejahteraan belum mampu diwujudkan setelah 15 tahun pasca bencana dan MoU Helsinki.

\section{DAFTAR PUSTAKA}

Basyar, M. Hamdan. "Peran Elit Lokal dalam Reintegrasi Gerakan Aceh Merdeka (GAM) Pasca MoU Helsinki" dalam Jurnal Penelitian Politik, Vol. 5, No. 1 (2008), h. 95-107.

Fetherston, A. B. Towards a Theory of United Nations Peacekeeping. New York: St. Martin's, 1994.

Galtung, Johan. "Three Approaches to Peace: Peacekeeping, Peacemaking and Peacebuilding" dalam Johan Galtung (ed.). Peace, War and Defense -Essays in Peace Research, Vol.2. Copenhagen: Ejlers,1976.

Herningtyas, Ratih \& Surwandono. "Diplomasi Bencana Alam sebagai Saran Meningkatkan Kerjasama Internasional" dalam Jurnal Hubungan Internasional, Vol 3, No. 2 (2014), h.181-188. 
Jemadu, Aleksius. "Proses Peacebuilding di Aceh: Dari MoU Helsinki Menuju Implementasi Undang-undang tentang Pemerintah Aceh" dalam Jurnal Hukum Internasional, Vol. 3, No. 4 (2006), h. 527-551.

Nurhasim, Moch. "Transformasi Gerakan Aceh Merdeka (GAM)" dalam Jurnal Penelitian Politik, Vol. 6, No. 1 (2009), h. 85-98.

Sinulingga, Anita Afriani. "Isu Bencana dan Prinsip-Prinsip Humanitarian dalam Studi Hubungan International” dalam Andalas Journal of International Studies, Vol.5, No.1 (2016), h. 17-27.

Sudirman Arifin \& Naura Nabila Haryanto. "Upaya Disaster Diplomacy Pemerintah Indonesia di Konflik Aceh 2005" dalam Sosiohumaniora - Jurnal Ilmu-ilmu Sosial dan Humaniora, Vol. 20, No. 3 (2018), h. 269-276.

Sukma, Rizal. "Mengelola Perdamaian di Aceh: Tantangan Pemeliharaan Pasca Konflik" dalam Patrick Daly (eds.). Aceh Pascatsunami dan Pascakonflik. Jakarta: Pustaka Larasan, ICAIOS, dan KITLV-Jakarta, 2012.

Tim Penulis Salemba Tengah. Mengawal Demokrasi: Pengalaman Jaringan Demokrasi Aceh dan RUUPA. Jakarta: YAPPIKA, 2007.

Wahono, Subur. "Implementasi Nota Kesepakatan (MoU) Helsinki di Provinsi Nangroe Aceh Darussalam Tahun 2005 sampai 2008”. Tesis. Jakarta: Program Pasca Sarjana Pengkajian Ketahanan Nasional, Universitas Indonesia, 2008.

Zainal, Suadi. "Transformasi Konflik Aceh dan Relasi Sosial Politik di Era Desentralisasi" dalam Masyarakat Jurnal Sosiologi, Vol. 21, No. 1 (2016), h. 81-108.

\section{Websita}

Aliansyah, Muhammad Agil. "Wacana Referendum Dinilai Tak Mewakili Aspirasi Msyarakat Aceh" dalam https://www.merdeka.com/peristiwa/wacanareferendum-dinilai-tak-mewakili-aspirasi-masyarakat-aceh.html diakses 1 Januari 2020.

ANTARANEWS. "67 Persen Publik Aceh Puas Dengan Perdamaian Yang Tercipta" dalam https://www.antaranews.com/berita/39859/67-persen-publik-aceh-puasdengan-perdamaian-yang-tercipta diakses 1 Januari 2020.

Taufiq, Nuri. "Fakta-fakta Seputar Aceh sebagai Provinsi Termiskin di Sumatera" dalam https://news.detik.com/kolom/d-4877496/fakta-fakta-seputar-acehsebagai-provinsi-termiskin-di-suma tera diakses 1 Februari 2020. 
Wardah, Fathiyah. "Perjanjian Helsinki Bisa Jadi Model Penyelesaian Konflik" dalam https://www.voaindonesia.com/a/perjanjian-helsinki-bisa-jadi-modelpenyelesaian-konflik/ 3058701.html diakses 1 Januari 2020. 